\title{
Implementasi Metode Topsis Pada Aplikasi Penilaian Karyawan Pada Enspire Studio
}

\author{
Maynacky $^{1)}$, Ribfan Hariyanto ${ }^{2}$, Halim Agung $^{3)}$ \\ Teknik Informatika, Fakultas Teknologi dan Desain, Universitas Bunda Mulia \\ Jl. Lodan Raya No.2, Pademangan, Jakarta Utara, 14430 \\ ${ }^{1)}$ Email: naki.joker@gmail.com, \\ ${ }^{2) E m a i l: ~ r i v a n h a r i y a n t o @ g m a i l . c o m, ~}$ \\ ${ }^{3) E m a i l: h a g u n g @ b u n d a m u l i a . a c . i d}$
}

\begin{abstract}
In this era of globalization, the competition companies in an industry increasingly tight. Companies are expected to provide the best service to consumers and its business partners. This causes the human resources required for showing the best performance with the company was thus able to compete with its competitors. And therefore the assessment of the most important elements are the employees of a company which could reflect how a company has the HR (human resources) are good or not, because Human Resource are a very important factor in a companies or institutions for the sake of the progress of the company. In this Research of the assessment application the method that we were using is TOPSIS algorithm (Technique for Order of Preference by Similarity to Ideal Solution) which aims to test whether the TOPSIS method implemented directly in the application of assessment into employees. Based on data for 10 months, as we can see the data of the final value in the table data to the actual assessment of the employee, and then compare the test results can be viewed by using the application shows the results of the final value is the same as the actual data the difference is only in decimal, based on the test so we can conclude that the success percentage rate method is $80 \%$. Hence the conclusion that can be drawn from the results of testing on TOPSIS method in the use of application implementations, we can use this method and applied this because the success rate is quite high. So that it can be used as a consideration for the final decision by the directiors.
\end{abstract}

Keywords: assessment employee system, employee performance, TOPSIS

\begin{abstract}
Abstrak: Di era globalisasi ini, persaingan perusahaan-perusahaan dalam suatu industri semakin ketat. Perusahaan dituntut untuk memberikan pelayanan terbaik kepada konsumen dan mitra bisnisnya. Hal ini menyebabkan sumber daya manusia dituntut untuk menampilkan performa yang terbaik dengan demikian perusahaan mampu bersaing dengan para kompetitornya. Dan maka dari itu Penilaian karyawan adalah elemen terpenting suatu perusahaan yang dimana bisa mencerminkan bagaimana suatu perusahaan memiliki SDM (Sumber Daya Manusia) yang bagus atau tidak, karena SDM adalah faktor yang sangat penting dalam sebuah perusahaan atau instansi demi kemajuan perusahaan tersebut. Pada metode riset ini aplikasi menggunakan metode algoritma TOPSIS (Technique for Order of Preference by Similarity to Ideal Solution) yang dimana bertujuan untuk menguji apakah metode TOPSIS tepat di implementasikan ke dalam aplikasi penilaian karyawan. Berdasarkan Pengujian data 10 bulan, jika di lihat dari data nilai akhir pada tabel data aktual penilaian karyawan, maka bisa dilihat hasil pengujian dengan menggunakan aplikasi menunjukan hasil nilai akhir yang sama hanya berbeda di angka di belakang koma, maka dapat kami simpulkan tingkat persentase keberhasilan metode yaitu 80\%. Maka kesimpulan yang bisa diambil dari hasil pengujian adalah penggunaan metode TOPSIS pada implementasi aplikasi penilaian karyawan bisa di gunakan dan di terapkan karena tingkat keberhasilan yang cukup tinggi. Sehingga dapat dipakai sebagai pertimbangan pengambilan keputusan akhir oleh pihak direksi.
\end{abstract}

Kata Kunci: kinerja karyawan, sistem penilaian karyawan, TOPSIS

\section{PENDAHULUAN}

Di era globalisasi ini, persaingan perusahaanperusahaan dalam suatu industri semakin ketat.
Perusahaan dituntut untuk memberikan pelayanan terbaik kepada konsumen dan mitra bisnisnya. Hal ini menyebabkan sumber daya manusia dituntut untuk menampilkan performa yang terbaik dengan 
demikian perusahaan mampu bersaing dengan para kompetitornya. Dan maka dari itu Penilaian karyawan adalah elemen terpenting suatu perusahaan yang dimana bisa mencerminkan bagaimana suatu perusahaan memiliki SDM (Sumber Daya Manusia) yang bagus atau tidak, karena SDM adalah faktor yang sangat penting dalam sebuah perusahaan atau instansi demi kemajuan perusahaan tersebut.

Dengan melakukan penilaian kinerja karyawan yang efektif, perusahaan mampu mengoptimalkan kompetensi karyawaannya demi tercapainya tujuan perusahaan. Selain itu kinerja karyawan juga akan optimal karena karyawan akan termotivasi untuk berkinerja lebih baik lagi dari hari ke hari. Hal ini berlaku pula sebaliknya, penilaian kinerja karyawan yang tidak efektif akan memberikan banyak dampak negatif bagi perusahaan. Mulai dari munculnya keluhan karyawan, turunnya motivasi kerja karyawan, hingga tingginya intensi turnover karyawan.

Fuzzy AHP-TOPSIS secara umum memberikan hasil yang memuaskan ketika diterapkan dalam proses seleksi kandidat. Namun, ia datang dengan batasan bahwa orang yang pendapatnya digunakan sebagai masukan harus memiliki pemahaman atau nilai yang sangat baik yang serupa dengan komite yang bertanggung jawab atas proses seleksi. Di sisi lain, Fuzzy AHP-TOPSIS dapat berfungsi sebagai alat yang sangat baik dalam memberikan masukan untuk proses seleksi yang diharapkan untuk memenuhi serangkaian nilai tertentu, karena lebih obyektif jika dibandingkan dengan manusia [5].

Metode TOPSIS fuzzy intuisionistik bermanfaat untuk mengevaluasi kinerja sumber daya manusia secara lebih komprehensif dan mencerminkan kualitas karyawan secara keseluruhan. Intuisi fuzzy mengatur metode TOPSIS dapat menghindari masalah bahwa indeks kualitatif sulit untuk mengukur metode penilaian kinerja tradisional, membuat hasil evaluasi relatif obyektif dan adil, dan memiliki akurasi dan pengoperasian yang tinggi [6].

Metode TOPSIS dapat digunakan di setiap kasus yang dapat diselesaikan dengan benar dengan menggunakan nilai untuk setiap alternatif dengan membandingkan setiap nilai, perhitungan kriteria alternatif dipercepat dan membandingkan antara alternatif adalah juga tidak sulit, untuk kasus dengan konsep multi kriteria dapat diatasi dengan metode ini, salah satu pengembangan yang dapat dilakukan dengan pendekatan ini adalah perlu menambah fungsionalitas sehingga proses perhitungan berat badan yang optimal tidak perlu dilakukan berulang kali. dengan hasil yang tidak jauh berbeda [7].
Penggunaan metode TOPSIS pada sistem pendukung keputusan dapat membantu manajerial dalam memperoleh kandidat yang kompeten dan juga diminimalkan dengan data yang diperoleh dari sistem pendukung keputusan [8].

Penerapan metode TOPSIS untuk menentukan salesman terbaik dapat berjalan dengan baik, konsep positif dan negatif yang ideal dapat memberikan perbandingan antara masing-masing alternatif dari setiap kriteria, penelitian ini jauh dari baik dan hasil yang diperoleh juga hanya berdasarkan satu metode saja dan untuk pengembangan lebih lanjut. dapat dikombinasikan atau dibandingkan dengan metode lain untuk mendapatkan hasil yang bervariasi [9].

Pada penelitian terdahulu yang menggunakan metode Topsis yang berjudul Sistem Pendukung Keputusan Kelompok Penentuan Karyawan Terbaik Menggunakan Metode Topsis dan Borda [10], peniliti menggunakan metode Topsis dan Borda untuk menentukan karyawan terbaik pada hotel LOMBOK GARDEN yang bersifat dinamis karena kriteria yang digunakan dapat diubah.

Pada penilitan terdahulu yang menggunakan metode Topsis yang berjudul Sistem Pendukung Keputusan Penentuan Karyawan Terbaik Menggunakan Metode Topsis [11], peniliti menggunakan Sistem Penunjang Keputusan atau SPK yang dikembangkan dengan menggunakan Metode Topsis dapat membantu dalam mengambil keputusan dalam menentukan karyawan terbaik. SPK yang dikembangkan dinyatakan memenuhi tujuan yang diharapkan dan hasil perhitungannya bisa lebih cepat dan akurat sehingga informasi yang dihasilkan dapat digunakan sebagai pendukung keputusan.

Lalu pada penilitan yang berjudul Pengembangan Sistem Informasi Penilaian Kinerja Karyawan Menggunakan Metode AHP dan TOPSIS [12], peneliti menggunakan metode AHP dan Topsis dalam pembobotan kriteria dan perankingan karyawan guna memperoleh karyawan terbaik dengan mengurangi tingkat subyektifitas penilaian.

\section{METODE PENELITIAN}

Technique For Order Preference by Similarity to Ideal Solution (TOPSIS) adalah salah satu metode pengambilan keputusan yang dikembangkan oleh Yonn dan Hwang pada tahun 1981 [2]. Metode ini memiliki ide dasar yaitu alternatif pilihan merupakan alternatif yang mempunyai jarak terkecil dari solusi ideal positif dan jarak terbesar dari solusi ideal negatif dari sudut pandang geometris dengan menggunakan 
jarak Euclidean. Solusi ideal positif didefinisikan sebagai jumlah dari seluruh nilai terbaik yang dapat dicapai untuk setiap atribut, sedangkan solusi negatifideal terdiri dari seluruh nilai terburuk yang dicapai untuk setiap atribut.

Langkah-langkah penyelesaian TOPSIS adalah dapat dilihat sebagai berikut:

1. Metode TOPSIS dimulai dengan membuat decision matriks. Decision matriks X menunjukan alternative yang akan di evaluasikan berdasarkan kriteria yang ada.

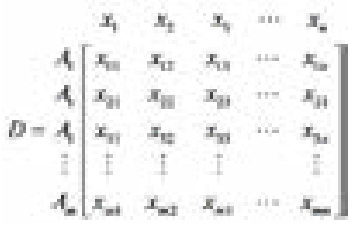

2. Membentuk matriks keputusan normalisasi

\section{Keterangan:}

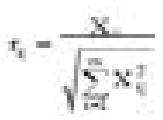

$\mathrm{r}_{\mathrm{ij}}$ : rating kinerja ternormalisasi dari alternatif pada masing- masing kriteria.

$\mathrm{x}_{\mathrm{ij}}$ : nilai setiap alternatif pada setiap kriteria.

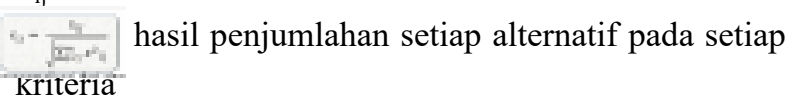

i $\quad: 1,2, \ldots \ldots ., \mathrm{m}$

j $\quad: 1,2, \ldots \ldots ., n$

3. Bobot Normalisasi

$y_{i j}=w_{i}, r_{i j} y_{i j}=w_{i} \cdot r_{i j}$

Keterangan:

$\mathrm{y}_{\mathrm{ij}} \quad$ : rating bobot ternormalisasi.

$\mathrm{w}_{\mathrm{i}} \quad$ : nilai setiap bobot preferensi.

$\mathrm{ri}_{\mathrm{j}} \quad$ : nilai dari matriks ternormalisasi.

i $\quad: 1,2, \ldots \ldots \ldots, m$

j $\quad: 1,2, \ldots \ldots \ldots, n$

4. Menentukan solusi ideal matriks positif dan matriks negatif dengan rumus berikut :

Solusi Ideal Positif

$\left.A^{+}=\left(y^{+}, y_{2, \ldots .,}^{+} y_{n}^{+}\right) 4\right)$

Keterangan:

$\mathrm{Y}^{+}{ }_{\mathrm{i}}$ : $\max \mathrm{y}_{\mathrm{ij}}$, jika $\mathrm{j}$ adalah atribut keuntungan. $\min y_{i j}$, jika $j$ adalah atribut biaya.

$\mathrm{A}^{+} \quad$ : solusi ideal positif

$\left(\mathrm{y}_{1}^{+}, \mathrm{y}_{2}^{+}, \ldots . \mathrm{y}_{\mathrm{n}}^{+}\right)$: nilai terbesar dari setiap alternatif terhadap setiap kriteria berdasarkan matriks ternormalisasi terbobot (y).

Solusi Ideal Negatif

$\left.A^{-}=\left(y^{-}, y_{2, \ldots}^{-}, y_{n}^{-}\right) 5\right)$

\section{Keterangan:}

$\mathrm{Y}_{\mathrm{i}}^{-} \quad$ : min $\mathrm{y}_{\mathrm{ij}}$, jika j adalah atribut keuntungan. $\max y_{i j}$ jika $j$ adalah atribut biaya.

$\mathrm{A}^{-} \quad$ : solusi ideal negatif

$\left(\mathrm{y}_{1}^{-}, \mathrm{y}_{2}^{-}, \ldots . \mathrm{y}_{\mathrm{n}}^{-}\right)$: nilai terkecil dari setiap alternatif terhadap setiap kriteria berdasarkan matriks ternormalisasi terbobot $(\mathrm{y})$.

5. Kalkulasi Pembagian

$\mathrm{D}+$ adalah alternatif dari solusi ideal positif :

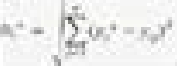

Dimana $\mathrm{i}=1,2,3, .,,, \mathrm{m}$

D - adalah alternatif dari solusi ideal negatif :

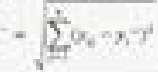

Dimana $\mathrm{i}=1,2,3, .,, \mathrm{,m}$

6. Menghitung nilai preferensi untuk setiap alternatif untuk menentukan ranking tiap-tiap alternatif yang ada maka perlu dihitung terlebih dahulu nilaipreferensi dari tiap alternatif. Perhitungan nilai preferensi dapat dilihat melalui persamaan tujuh.

$V_{i}=\frac{D_{i}^{-}}{D_{i}^{-}+D_{i}^{+}}$

Keterangan:

$\mathrm{V}_{\mathrm{i}} \quad$ : nilai preferensi.

$\mathrm{D}_{i}^{+}$: jarak alternatif dengan solusi ideal positif.

$\mathrm{D}_{i}^{-} \quad$ : jarak alternatif dengan solusi ideal negatif.

7. Rank Alternative

Alternative $\mathrm{C}^{+}$diurutkan dari nilai yang terbesar ke nilai terkecil, lalu alternative dengan nilai $\mathrm{C}^{+}$ terbesar adalah pilihan terbaik

Metode pengembangan sistem yang digunakan dalam penelitian ini adalah metode waterfall dengan urutan proses sebagai berikut:

Requirement Analysis and Definition. Pada tahap ini dikumpulkan secara lengkap kebutuhan mengenai perangkat lunak, kemudian peniliti menganlisis apa saja kebutuhan-kebutuhan yang dibutuhkan pada perangkat lunak.

System and Software Design. Pada tahap ini penliti melakukan desain system yang akan dibuat setelah kebutuhan selesai dikumpulkan secara lengkap.

Implementation and Unit Testing. Pada proses ini desain program diterjemahkan ke dalam kodekode dengan menggunakan Bahasa pemograman yang sudah ditentukan. Program yang dibangun langsung diuji dengan tujuan agar program dapat 
berjalan dengan baik. Integration and System Testing. Pada proses ini adalah penyatuan unit-unit program. Setelah ini dilakukan pengujian dengan sampel data karyawan yang diperoleh untuk sinkronisasi data real dengan database yang dibuat.

Operation and Maintance. Pada proses ini dilakukan pengujicobaan perangkat lunak perhitungan hasil kinerja karyawan dari kriteria yang ditentukan berdasarkan data sampel yang ada. Tujuan dari proses ini adalah mengurangi kesalahan yang ada pada perangkat lunak yang dibuat dan sesuai dengan kebutuhan.

Use case diagram mengGambarkan aktor yang terlibat dalam kegiatan penilaian kinerja karyawan berdasarkan inputan data asli, serta memproses penilaian dengan kriteria yang sudah ditentukan. Use case diagram diGambarkan pada Gambar 1.
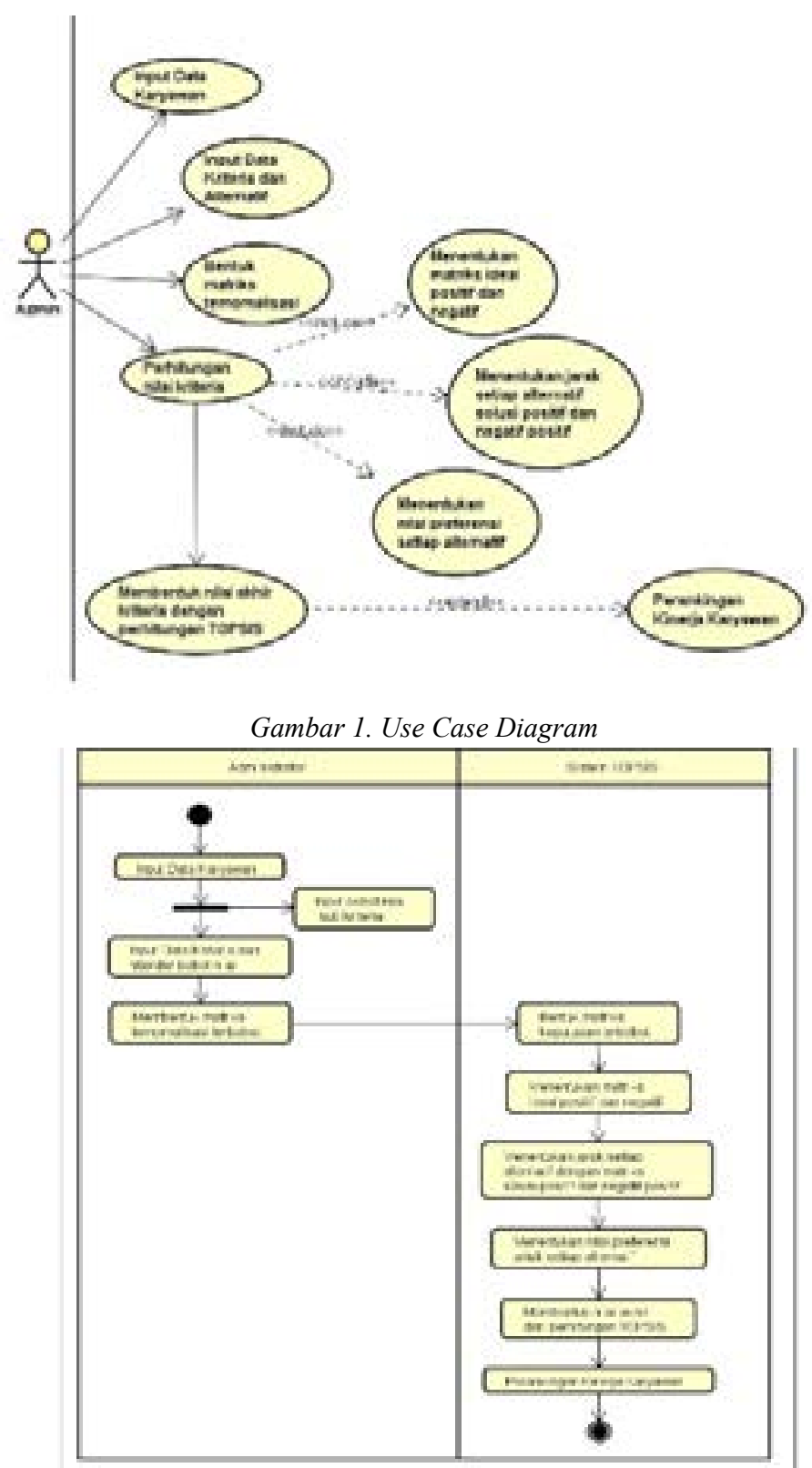

Gambar 2. Activity Diagram

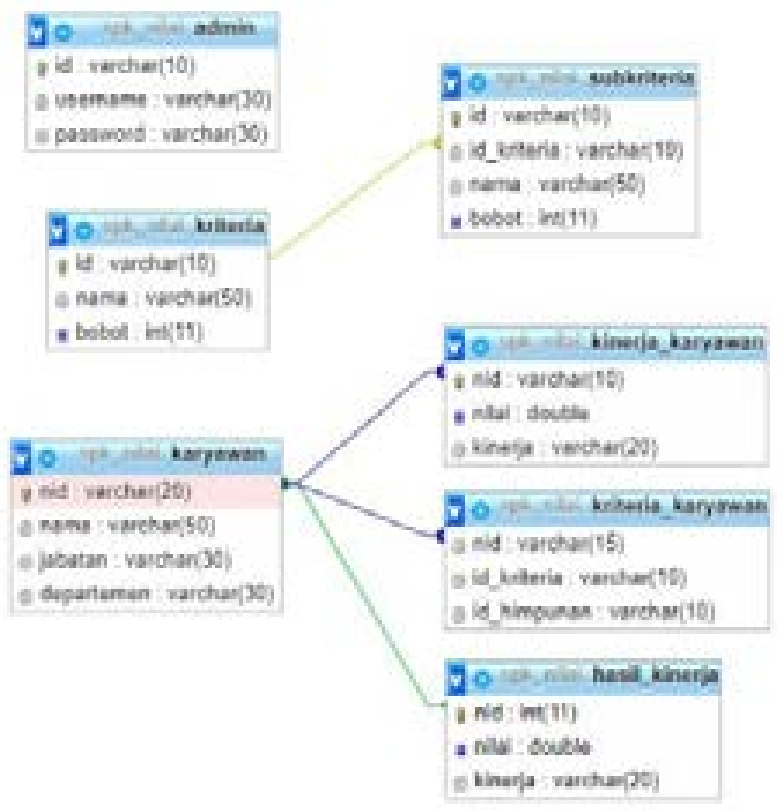

Gambar 3. ERD Diagram database

Activity diagram mengGambarkan berbagai alir aktivitas dalam sistem yang sedang dirancang, bagaimana masing-masing alir berawal, dan bagaimana mereka berakhir. Activity diagram diGambarkan pada Gambar 2.

Perancangan database menggunakan Entity Relationship Diagram (ERD) mengGambarkan interaksi dan relasi antar entitas dalam sistem yang dapat kita lihat pada Gambar 3.

\section{HASIL DAN PEMBAHASAN}

Tampilan Gambar 4 adalah halaman login ketika aplikasi dijalankan.

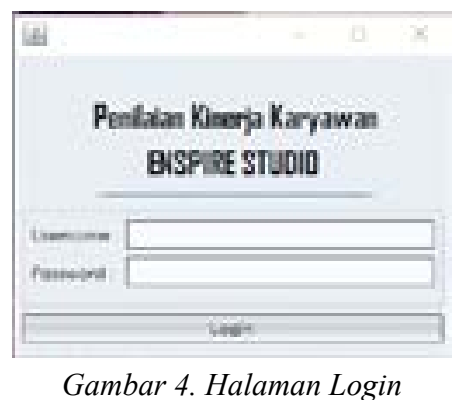

Tampilan Gambar 5 merupakan tampilan halaman utama ketika user sudah login kedalam aplikasi. Keterangan: Admin: Sebagai penampung Data administrator pengguna; Kriteria: Sebagai penampung Data penilian kategori kriteria; Sub Kriteria: Sebagai penampung standar bobot nilai kriteria; Karyawan: Sebagai penampung Data dan informasi Karyawan; Kriteria Karyawan: Sebagai penampung hasil nilai kriteria per karyawan; dan Penilaian Kinerja: Sebagai proses perhitungan nilai karyawan Karyawan berdasarkan nilai kriteria karyawan yang diinputkan. 


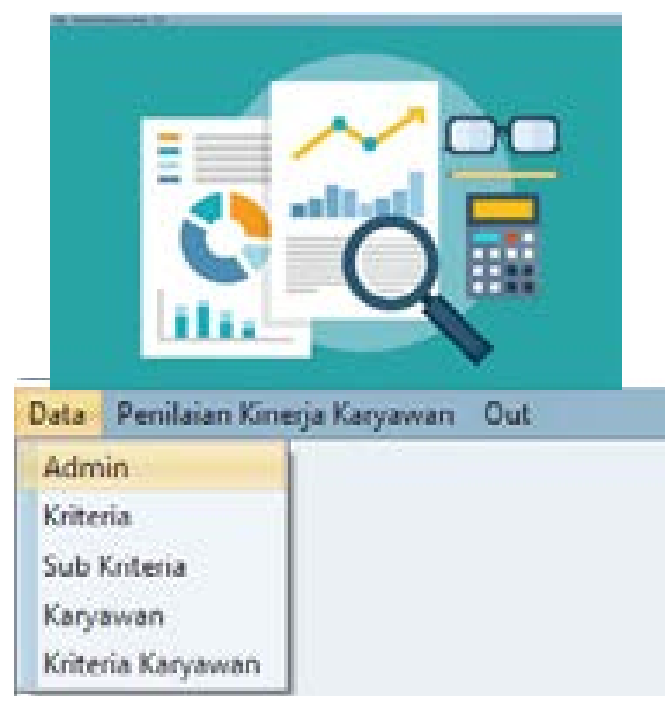

Gambar 5. Halaman menu dan sub menu

Tampilan Gambar 6 merupakan tampilan untuk menambahkan akun pengguna baru sebagai administrator.

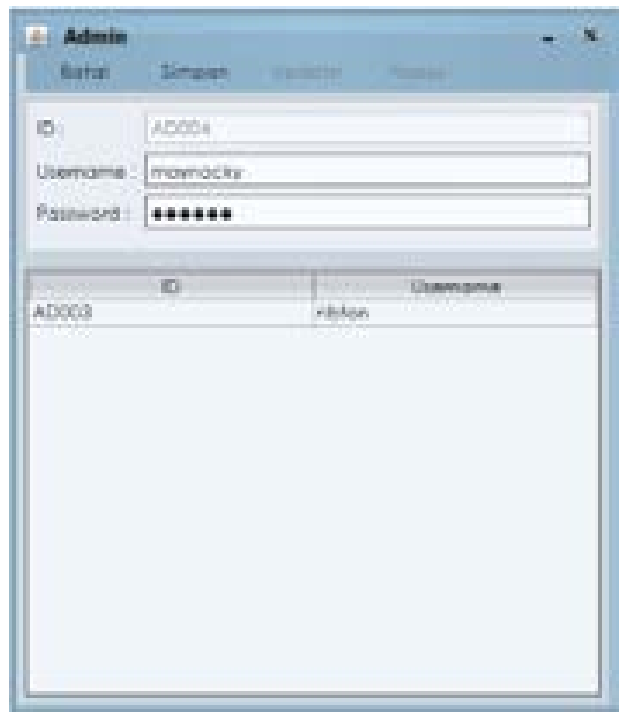

Gambar 6. Halaman user administrator

Tampilan Gambar 7 merupakan tampilan halaman untuk mmenginput kategori penilaian kriteria dan juga standar minimal bobot nilai yang sudah ditetapkan dalam menilai kinerja karyawan. Form Sub Kriteria itu sendiri sebagai acuan bobot nilai dari setiap kriteria yang ada.

Tampilan Gambar 8 merupakan tampilan halaman untuk menginput data karyawan yang bekerja. Tampilan Gambar 9 merupakan tampilan halaman kriteria karyawan untuk menginput dan menampilkan nilai dari setiap kriteria yang ada per karyawan. Gambar 10 merupakan tampilan apabila user memproses penilaian kinerja karyawan berdasarkan inputan nilai kriteria karyawan. Ketika proses selesai maka akan ditampilkan hasil berupa tabel perankingan.

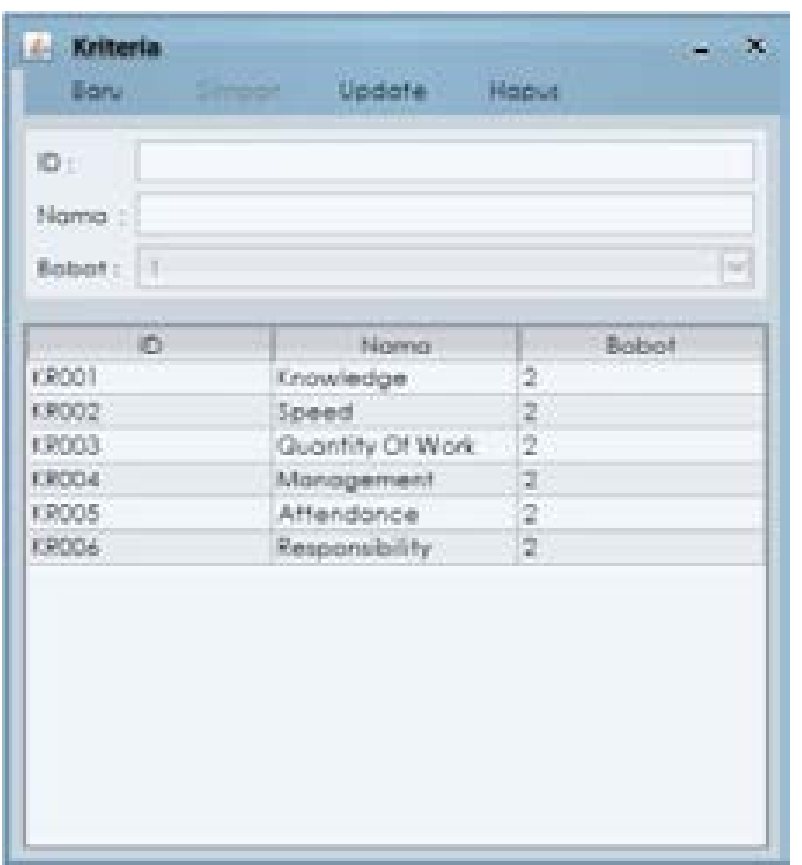

Gambar 7 Halaman kriteria

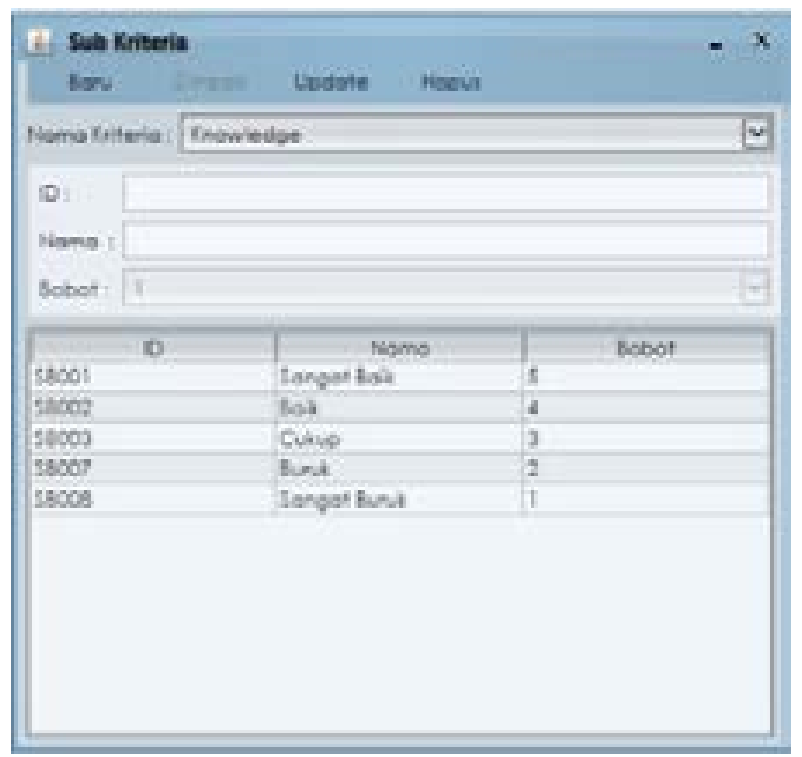

Gambar 8. Halaman Data Karyawan

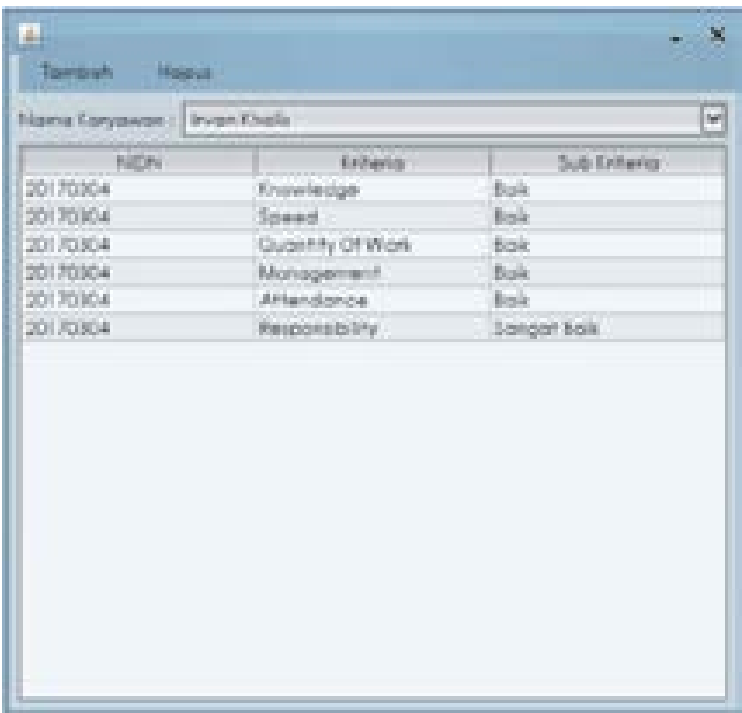

Gambar 9. Halaman Kriteria Karyawan 


\begin{tabular}{|c|c|c|c|c|c|c|c|c|c|c|c|}
\hline \multicolumn{6}{|l|}{ B } & & & & & & $-x$ \\
\hline \multicolumn{6}{|c|}{ 1. Whatlis cenoutuver. } & \multicolumn{6}{|c|}{2 Mothat Terromaleori Torbobet } \\
\hline twoil & xemp & ment & came & reche & reme & cant & cemp & rena & cens & temses & cond \\
\hline 5 & 4 & 4 & 4 & 5 & s & 21052004 & 1.6027002 & 15818001 & 1.4721716 & 2001212 & $20075801 \ldots$ \\
\hline 5 & 3 & 5 & + & 3 & + & 21003980 & $2254+1745$ & $20007501-$ & Iaran71/: & 20412414 & 19510001 \\
\hline 5 & it & 4 & 4 & 5 & 4 & $216007 \%$ & $105000 \% 2$ & $13,80001$. & 1.0731716 & 20012012 & 19510001 \\
\hline 2 & o & 4 & s & 2 & + & $2105 a r y$. & 22541740.2 & 1550000 & 23414642 & 204246 & 1.7310001 \\
\hline 5 & 4 & 4 & 2 & 5 & 4 & 21063796 & 10233292 & 19510000 & 18731716 & $204: 2414$ & 19510001 \\
\hline 4 & 5 & 4 & 5 & 5 & A & $1 \cos 008$. & 22541749 & $13516000^{4}$ & 23414645 & $200: 2012$ & 1,9510001 \\
\hline \multicolumn{6}{|c|}{3 Solui ded fosent? } & \multicolumn{6}{|c|}{ 4. Seluaildealkegont } \\
\hline mol & $\times 00000$ & xpeos & $\cos 4$ & knoos & 10000is & knooi & knoos & knoas & kenod & 69006 & kesos \\
\hline 00 & 82092320 & 0.2300052. & 52197902 & 00 & Do & 0.1773069 & oa & 100 & 00 & 00 & $0.2300+32$ \\
\hline go & DQ & 00 & 0217002 & 00 & ozsexp3z. & $0 \mathrm{~m}$ mon & 0.200000 & 02560192 & od & 00 & Do \\
\hline 00 & 0.2002520. & 0.2650952 & $0.21 \% 302$ & 00 & 0.22600152 & $0.177304 \%$ & 0.0 & 00 & 0.0 & 00 & 0.0 \\
\hline 00 & 00 & 0.2300952 & 00 & 00 & 0.23000532 & 0.17306 & 020202520 & 100 & 0.2192982. & 00 & 0,0 \\
\hline 00 & 02000520 & 0.2360952 & 02192982 & 0.0 & $02 x e 0952$ & 0.173300 & 00 & 100 & 00 & 00 & 00 \\
\hline a Imas. & Do & a 230006? & sis & 00 & 02 atso52. & ab & $83 \cos 350$ & ab & 02162022 & os & Do \\
\hline \multicolumn{12}{|c|}{ 5. Peoriknoas } \\
\hline \multicolumn{4}{|c|}{ Nomokronower } & \multicolumn{4}{|c|}{ Nints } & \multicolumn{4}{|c|}{ Cimara } \\
\hline \multicolumn{4}{|c|}{ Derden Faurdhos } & \multicolumn{4}{|c|}{44226103045200920} & \multicolumn{4}{|l|}{ Cutue } \\
\hline \multicolumn{4}{|l|}{ rros Colit } & \multicolumn{4}{|c|}{ 5) $76783 \mathrm{c} 3 \mathrm{Y}=023 \mathrm{~m}$} & \multicolumn{4}{|l|}{ Cuho } \\
\hline \multirow{2}{*}{\multicolumn{4}{|c|}{$\begin{array}{l}\text { Eeroe More } \\
\text { T. mote }\end{array}$}} & \multirow{2}{*}{\multicolumn{4}{|c|}{ 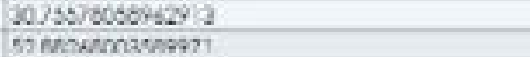 }} & \multicolumn{4}{|l|}{ Gunk } \\
\hline & & & & & Wuonent & & & \multirow{2}{*}{\multicolumn{4}{|c|}{ Aunt }} \\
\hline \multicolumn{4}{|l|}{ Tosil } & \multicolumn{4}{|c|}{ 30 55878069048013} & & & & \\
\hline \multicolumn{4}{|l|}{ hen Mulugel } & \multicolumn{4}{|c|}{ 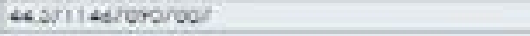 } & \multicolumn{4}{|l|}{ entup } \\
\hline
\end{tabular}

\section{SIMPULAN}

Berdasarkan hasil penelitian mengenai "Implementasi Metode TOPSIS pada Aplikasi Penilain Karayawan pada Enspire Studio" yang dilakukan melalui observasi, penelitian dan pengujian data. Peneliti menyimpukan bahwa penilaian karyawan menggunakan algoritma TOPSIS sangat efektif dengan poin-poin berikut: Perhitungan kinerja karyawan menggunakan algoritma TOPSIS dapat diterapkan pada penilaian kinerja karyawan setiap bulannya; Tingkat keakuratan dalam kesamaan data 10 bulan terakhir dengan hasil analisa algoritma TOPSIS mencapai persentase $80 \%$; dan Perangkingan yang diambil merupakan hasil akhir setelah perhitungan setiap solusi alternaif positif maupun negatif., sebagai pertimbangan pengambilan keputusan akhir oleh pihak direksi.

\section{DAFTAR PUSTAKA}

[1] A. S Rosa , dan M.Shalahuddin. Rekayasa Perangkat Lunak Struktur dan Berorientasi Objek, Edisi Kedua, Informatika, Bandung. ISBN: 978-602-151-405-4. 2014

[2] C.L. Hwang, \& K. Yoon. Multiple Attribute Decision Making: Methods and Applications, Springer-Verlag, New York. http://dx.doi.org/10.1007/978-3-642-
48318-9. 1981

[3] D. Clark. Beginning C\#Object-Oriented Programming, Apress, New York. ISBN-13 (electronic): 978-1-43023531-6. 2011

[4] M. Salahuddin \& Rosa. Pemograman J2ME Belajar Cepat Pemograman Perangkat Telekomunikasi Mobile, Edisi Revisi Kedua Informatika, Bandung. ISBN: 978602-8758-01-7. 2010

[5] R. P. Kusumawardani \& M. Agintiara. Application of Fuzzy AHP-TOPSIS Method for Decision Making in Human Resource Manager Selection Process, Procedia Computer Science 72, 638 - 646. doi: 10.1016/j. procs.2015.12.173. 2015

[6] W. Yinghui \& L. Wenlu. The Application of Intuitionistic Fuzzy Set TOPSIS Method in Employee Performance Appraisal, International Journal of u- and e- Service, Science and Technology, Vol.8, No.3 (2015), pp.329344. ISSN: 2005-4246 IJUNESST. 2015

[7] Jasri, D. Siregar \& R. Robbi. Decision Support System Best Employee Assessments with Technique for Order of Preference by Similarity to Ideal Solution, International Journal of Recent Trends in Engineering \& Research (IJRTER), Vol.3, Issue 03 (2017). ISSN: 2455-1457. 2017

[8] R. Rahim, et al. TOPSIS Method Application for Decision Support System in Internal Control for Selecting Best Employees, Journal of Physics: 
Conference Series, Conf. Series 1028 (2018). doi :10.1088/1742-6596/1028/1/012052. 2018

[9] V. N. S. Lestari, et al. Technique for Order Preference by Similarity to Ideal Solution as Decision Support Method for Determining Employee Performance of Sales Section, International Journal of Engineering \& Technology, Vol.7 (2.14) (2018) 281 - 285. ISSN: 281285. 2018

[10] I. M. A. B. Saputra \& R. Wardoyo. Sistem Pendukung Keputusan Kelompok Penentuan Karyawan Terbaik Menggunakan Metode Topsis dan Borda, IJCCS, Vol.11, No.2, July 2017, pp. 165 176. ISSN: 19781520. 2017. 2017
[11] H. Hertyana. Sistem Pendukung Keputusan Penentuan Karyawan Terbaik Menggunakan Metode TOPSIS, Jurnal Ilmu Pengetahuan dan Teknologi Komputer, Vol.4, No.1, Agustus 2018. E-ISSN: 2527-4864. 2018

[12] F. A. Nazilla, N. Santoso, \& I. F. Rozi. Pengembangan Sistem Informasi Penilaian Kinerja Karyawan Menggunakan Metode AHP dan TOPSIS, Jurnal Informatika Polinema, Volume 3, Edisi 4, Agustus 2017. ISSN: 2407-070X. 2017 